\title{
Strategi Pendidikan Islam Menghadapi Problematika Globalisasi
}

\author{
ADE IMELDA FRIMAYANTI \\ Fakultas Pendidikan Agama Islam Universitas Lampung \\ Jl. Prof. Dr. Soemantri Bojoneforo No.1 Kota Bandar Lampung \\ Hp: 081379163615
}

\begin{abstract}
Abstrak: Globalisasi memberikan efek positif dan negatif bagi umat Islam yang kemudian menjadi problema atau tantangan pendidikan Islam untuk mengatasi efek negatif dan menyiakan generasi muslim yang handal menghadapi tantangan globalisasi. Problema yang dihadapi pendidikan Islam menghadapi era globalisasi di antaranya adalah: Kekurangan sumber daya tenaga pendidik yang profesional, Kesejahteraan tenaga pendidik masih rendah, Orientasi pembelajaran lebih bersifat kognitif, Manejemen madrasah kurang optimal, Krisis akhlak, Persepsi masyarakat terhadap madrasah masih banyak kurang baik. Strategi pendidikan Islam dalam menghadapi tantangan globalisasi antara lain: Membangun Paradigma Pendidikan Islam yang sebenarnya, Melaksanakan Pendidikan Afektif, Meningkatkan mutu tenaga pendidik.
\end{abstract}

Kata kunci: pendidikan Islam, globalisasi, promblematika dan strategi.

\section{PENDAHULUAN}

Kehidupan globalisasi telah dengan nyata melanda kehidupan kita. Suka ataupun tidak suka, ummat Islam harus menghadapinya dengan segala implikasinya. Ciri-ciri kehidupan global antara lain: Pertama, terjadinya pergeseran dari konflik ideologi dan politik ke arah persaingan perdagangan, investasi dan informasi; dari keseimbangan kekuatan (balance of power) ke arah keseimbangan kepentingan (balance of interest). Kedua, hubungan antar negara/bangsa secara struktural berubah dari sifat ketergantungan (dependency) ke arah saling ketergantungan (interdepen-dency), hubungan yang bersifat primordial berubah menjadi sifat tergantung kepada posisi tawar-menawar (bargaining position).
Ketiga, batas-batas geografis hampir kehilangan arti operasionalnya. Kekuatan suatu negara ditentukan oleh kemampuannya memanfaatkan keunggulan komparatif (comparative advantage) dan keunggulan kompetitif (competitive advantage). Keempat, persaingan antar negara sangat diwarnai oleh perang penguasaan teknologi tinggi. Setiap negara terpaksa menyediakan dana yang besar bagi penelitian dan pengembangan. Kelima, terciptanya budaya dunia yang cenderung mekanistik, efisien, tidak menghargai nilai dan norma yang secara ekonomi tidak efisien (Maksum \& Ruhendi, 2004: 281).

Pergaulan global dengan cirinya seperti diuraikan diatas, disamping mendatangkan sejumlah kemudahan 
bagi manusia, juga mendatangkan sejumlah efek negatif yang dapat merugikan dan mengancam kehidupan. Pendidikan Islam harus mampu memainkan peranan yang sangat penting dalam mempersiapkan generasi menghadapi era yang penuh dengan tantangan. Pendidikan Islam harus mampu menyelenggarakan proses pembekalan pengetahuan, penanaman nilai, pembentukan sikap dan karakter, pengembangan bakat, kemampuan dan keterampilan, menumbuh-kembangkan potensi aqal, jasmani dan ruhani yang optimal, seimbang dan sesuai dengan tuntutan zaman.

Umat Islam nampaknya masih kurang memiliki daya saing global karena keterbelakangan sistemik yang belum bisa dieliminir melalui upaya melejitkan potensi dan kemampuan kompetitif serta kooperatif umat islam. Sudah saatnya umat islam menetapkan strategi mewujudkan kemajuan dan kedamaian dalam tatanan dunia baru islam tidak hanya melalui peran politik, tetapi justru melalui pemantapan peran kulturalisasi islam secara komperehensif khususnya di bidang pendidikan.

Semua persoalan yang memperlemah kondisi umat harus melalui upaya strategis memperkuat sumber daya umat Islam, baik sumber daya manusia, alam, sosial, IPTEK, maupun modal/keuangan. Salah satu upaya strategis kearah peningkatan kualitas umat adalah dengan membenahi sistem pendidikan yang secara langsung berkaitan dengan pengembangan sumberdaya manusia berkualitas sesuai keperluan lokal, Nasional, regional, dan global. Ketersediaan sumberdaya manusia (human resources) atau SDM unggul yang mampu menjawab persaingan dan bekerja sama mewujudkan kebaikan untuk semua. harus menjadi visi perjuangan umat dalam semua level dan segmen kehidupan.

Berdasarkan latar belakang masalah tersebut, maka dirumuskan beberapa masalah antara lain adalah: Problematika apasajakah yang dihadapi pendidikan Islam pada era globalisasi? ; dan Bagaimana strategi pendidikan Islam dalam menghadapi era globalisasi?

\section{KONSEP TEORI \\ Pendidikan Islam}

Pendidikan memikul beban amanah yang sangat berat, yakni memberdayakan potensi fitrah manusia yang condong kepada nilai-nilai kebenaran dan kebajikan agar ia dapat memfungsikan dirinya sebagai hamba, yang siap menjalankan risalah yang dibebankan kepadanya yakni "khilafah fil ardl". Oleh karena itu pendidikan berarti merupakan suatu proses membina seluruh potensi manusia sebagai: makhluk yang: beriman, berfikir, dan berkarya untuk kemaslahatan diri dan lingkungannya. Sebagaimana yang dikemukakan Hasmiyati Gani Ali, bahwa pendidikan adalah proses mempersiapkan masa depan anak didik dalam mencapai tujuan hidup secara efektif dan efisien (Ali, 2008: 13).

Islam sebagai agama yang sempurna telah memberikan pijakan yang jelas tentang tujuan dan hakikat pendidikan, yakni memberdayakan potensi fitrah manusia yang condong kepada nilai-nilai kebenaran dan kebajikan agar ia dapat memfungsikan dirinya sebagai hamba. Oleh karena itu pengertian pendidikan Islam adalah "segala usaha untuk memelihara dan mengembangkan fitrah manusia serta sumberdaya insani yang ada padanya menuju terbentuknya manusia seutuhnya (insan kamil) sesuai dengan 
norma Islam" (Ahmadi, 2001: 20). Menurut Marimba (1974: 23), pendidikan Islam adalah membimbing jasmani dan rohani berdasarkan hukum agama Islam menuju terbentuknya kepribadian utama menurut ukuran Islam. Pendapat lain memberikan pengertian pendidikan Islam adalah "usaha sistematis, pragmatis dalam membentuk anak didik agar mereka hidup sesuai dengan ajaran agama Islam" (Zuhairini, 1980: 25). Menurut Ramayulis (1994:3-4), pendidikan Islam adalah mempersiapkan manusia supaya hidup dengan sempurna dan berbahagia, mencintai tanah air, tegap jasmaninya, sempurna budi pekertinya, teratur pikirannya, halus perasaannya, mahir dalam pekerjaannya, manis tutur katanya baik dengan lisan atau tulisan. Pendidikan Islam itu membimbing anak didik dalam perkembangan dirinya, baik jasmani maupun rohani menuju terbentuknya kepribadian yang utama pada anak didik nantinya yang didasarkan pada hukum-hukum islam (Isma'il: 2008 36).

Berdasarkan beberapa penger-tian di atas, dapat diambil suatu kesimpulan bahwa yang dimaksud dengan pendidikan Islam adalah suatu usaha manusia untuk mendidik atau menjadikan seseorang itu beriman, bertakwa dan memiliki akhlak yang mulia. Dengan demikian pendidikan Islam merupakan sebuah proses transformasi dan internalisasi nilai-nilai ajaran islam terhadap peserta didik, melalui proses pengembangan fitrah manusia agar memperoleh keseimbangan hidup dalam semua aspeknya.

Adapun tujuan pendidikan Islam apabila melihat pengertiannya adalah untuk menjadikan peserta didiknya menjadi manusia yang beriman, bertakwa dan berakhlak mulia. Oleh karena itu menurut M. Athiyah al-
Abrasyi (1970:1), tujuan pendidikan Islam yang pokok dan terutama adalah untuk mendidik budi pekerti dan pendidikan jiwa. Karena itulah menurut beliau semua mata pelajaran haruslah mengandung pelajaran akhlak dan setiap guru haruslah memperhatikan akhlak.

Pendapat lain menyebutkan bahwa tujuan pendidikan Islam adalah pembinaan kepribadian anak didik yang sempurna, peningkatan moral, tingkah laku yang baik dan menanamkan rasa kepercayaan anak terhadap agama dan kepada Tuhan, serta mengembangkan intelegensi anak secara efektif agar mereka siap untuk mewujudkan kebahagiaannya di masa mendatang (Arief, 2002: 24). Tujuan pendidikan Islam adalah agar manusia memiliki kemampuan untuk mengelola dan memanfaatkan potensi pribadi, sosial dan alam sekitar bagi kesejahteraan hidup di dunia sampai dengan akhirat (Arifin, 1993:138).

Dapat dipahami bahwa pendidikan Islam bertujuan untuk menyiapkan peserta didik menjadi manusia yang dapat hidup bahagia di dunia maupun di akhirat. Dan untuk dapat menyiapkan peserta didik dapat hidup bahagia di dunia maupun di akhirat tidak hanya dengan memberikan pendidikan umum akan tetapi juga dengan memberikan dan menanamkan nilai-nilai agama Islam dalam diri peserta didik tersebut, sehingga dengan pendidikan agama tersebut dapat mengontrol segala tingkah lakunya di dunia dan dapat menyelamatkan hidupnya kelak di akhirat. Sebagaimana firman Allah SWT:

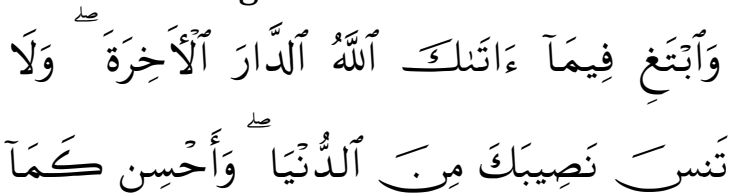




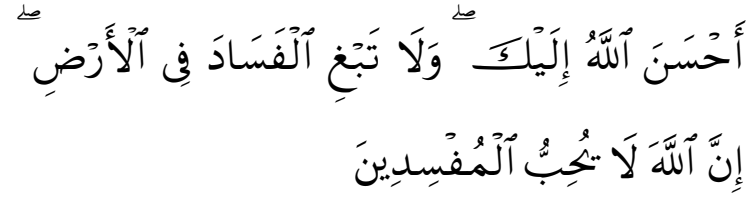

Artinya: "Dan carilah pada apa yang Telah dianugerahkan Allah kepadamu (kebahagiaan) negeri akhirat, dan janganlah kamu melupakan bahagianmu dari (kenikmatan) duniawi dan berbuat baiklah (kepada orang lain) sebagaimana Allah Telah berbuat baik, kepadamu, dan janganlah kamu berbuat kerusakan di (muka) bumi. Sesungguhnya Allah tidak menyukai orangorang yang berbuat kerusakan." (AlQashash: 77).

\section{Hakikat Globalisasi}

Globalisasi artinya proses masuknya ke ruang lingkup dunia (Depdiknas, 2002: 366). Menurut David Held dan Anthony Mc.Crew, kata globalisasi dapat diartikan dalam pemaknaan yang beragam seperti kedekatan jarak, ruang, dan waktu yang menyempit, pengaruh cepat serta dunia yang menyempit. Dengan demikian kata globalisasi secara sederhana dapat diartikan sebagai melenyapkan dinding dan jarak antara satu bangsa dengan bangsa yang lain, anatara satu kebudayaan yang satu dengan kebudayaan yang lain. Dengan kata lain merubah dunia menjadi perkampungan dunia (Baharudin, 2011: 2).

Berdasarkan beberapa pendapat tersebut dipahami bahwa globalisasi adalah suatu proses di mana antar individu, antar kelompok, dan antar negara saling berinteraksi, bergantung, terkait, dan memengaruhi satu sama lain yang melintasi batas negara, yakni integrasi bangsa-bangsa dalam satu sistem global. Yang menghilangkan batas-batas geografis, politik, ekonomi, sosial dan lainnya. Sehingga, seakan tidak ada lagi rahasia bagi suatu negara tanpa diketahui oleh negara lain. Karena keunggulan teknologi informasi yang menyebabkan akses informasi begitu mudah dan tanpa batas. Sebagaimana yang dikemukakan Abudin Nata (2005: 70), bahwa "era global keadaan masyarakat ditandai dengan penggunaan teknologi yang canggih berupa teknologi informasi".

Globalisasi yang saat ini melanda dunia membawa dan mengandung nilainilai, konsep, dan teori-teori yang merambah dalam semua bidang kehidupan, baik dalam bidang politik, sosial, ekonomi, bahkan budaya serta pendidikan. Globalisasi telah membawa masyarakat dunia pada sebuah tatanan budaya global. Isu-isu semacam civil society, hak asasi manusia, liberalisasi, multikuluralisme dan sebagainya berkembang dengan pesat menjangkau pelosok-pelosok Negara.

\section{HASIL DAN PEMBAHASAN \\ Problematika Pendidikan Islam di Era Globalisasi}

Globalisasi mempunyai pengaruh yang sangat besar dalam hidup dan kehidupan manusia dalam berbagai asfek kehidupan, baik aspek ekonomi, politik, budaya, sosial, bahkan pendidikan. Dalam hal ini globalisasi telah mengubah kehidupan sehari-hari terutama dirasakan sekali di Negaranegara berkembang terutama di Negara Islam seperti Indonesia. Ketergantungan dalam aspek ekonomi, politik dan budaya barat menjadi penomena baru bagi masyarakat Indonesia, sehingga globalisasi memberikan dampak negatif dan positif pada bangsa Indonesia. Model dan cara berpakaian yang tidak Islami, jenis makanan yang dinikmati, sudah jauh dari menu dan kekhassan local, pengaruh bebas dan pergaulan muda-mudi yang tidak mengenal tata karma dan nilai-nilai keislaman sudah 
terlihat dimana-mana. Semua ini merupakan sebagian dari pengaruh negatif globalisasi (Baharudin, 2011: 67).

$\begin{array}{rrr}\text { Begitu } & \text { juga dalam } & \text { aspek } \\ \text { pendidikan, } & \text { globalisasi } & \text { telah }\end{array}$
berpengaruh terhadap penyelenggaraan pendidikan, baik terhadap tujuan, proses hubungan peserta didik dan pendidik, etika, metode maupun yang lainnya. Dalam hal tujuan misalnya, tujuan pendidikan terdapat kecenderungan yang mengarah pada materialisme, sehingga hal yang pertam yang mungkin ditanyakan oleh orang tua siswa atau siswa adalah lembaga pendidikan tempat ia belajar dapat menjamin masa depan kehidupannya. Demikian juga dengan kurikulumnya, lebih mengarah pada bagimana hal-hala yang materialistic itu dapat dicapai. Dalam hal ini belajar lebih terpokus pada aspek penguasaan ilmu (kognitif) belaka ketimbang bagaimana seorang siswa memiliki sikap yang sesuai dengan nilai-nilai Islam (Baharudin, 2011: 6-7).

Lebih rinci Baharudin (2011: 8-9) menjelaskan ada beberapa kelemahan sekaligus problema pendidikan Islam menghadapi era globalisasi yaitu: (1) Kualitas lembaga pendidikan Islam secara umum masih menyedihkan. Meskipun ada bebarapa lembaga pendidikan Islam seperti madrasah yang sudah mampu mengungguli kualitas sekolah umum, tetapi secara umum kualitas lembaga pendidikan Islam belum memadai; (2) Citra lembaga pendidikan Islam relatif rendah. Adalah suatu kenyataan bahwa dalam ranking kelulussan lembaga pendidikan Islam umumnya berada didalam urutan dibawah sekolah umum; (3) Kualitas dan kuantitas guru yang belum memadai. Guru adalah kunci keberhasilan dalam pendidikan. Jika Gurunya berkualitas rendah dan rasio siswa tidak memadai, maka out put pendidikannya dengan sendirinya akan rendah pula; (4) Gaji Guru secara umum masih kecil; (5) Latar belakang siswa di lembaga pendidikan Islam pada umumnya dari keluarga kelas menengah ke bawah; (6) Tuntutan kompetisi dan kompetensi yang semakin meningkat; (7) Gempuran pengaruh globalisasi asing dalam bidang ekonomi, politik dan budaya yang cenderung menggeser budaya nasional yang religious. Hal ini ditandai dengan semakin menonjolnya orientasi global dalam bidang fun, fashion, dan food dikalangan remaja kita; (8) Kenakalan remaja yang semakin menghawatirkan antara lain dalam bentuk penyalahgunaan narkoba yang semakin meluas; dan (9) Harapan umat agar lembaga pendidikan Islam mampu melahirkan orang-orang yang intelek, tetapi alim dan orang-orang alim yang intelek. Harapan ini yang harus dijawab dengan sungguh-sungguh dan terus menerus mengupayakan kualitas lembaga pendidikan Islam yang terus meningkat.

Pendapat lain menjelaskan beberapa problema yang dihadapi lembaga pendidikan Islam ada dua yaitu bersifat internal dan eksternal (Muhaimin, 2013: 24). Dari segi internal, tantang yang dihadapi adalah menyangkut: (1) Mutu. Penyelenggaraan dan pengelolaan madrasah umumnya belum dapat melahirkan lulusan yang berkualitas; (2) Pendidik. sebagian besar tenaga pendidik dan kependidikan di madrasah belum berkualifikasi sesuai dengan tuntutan perundang-undangan; (3) Kurikulum. Sebagian besar madrasah belum dapat mengimplementasikan standar isi dan belum sepenuhnya dapat mencapai standar kompetensi lulusan minimal. Persentasi lulusan ujian nasional cukup menggembirakan, kurang lebih 92\%, tetapi perolehan nilai rata-rata masih 
rendah; (4) Manajemen. Penyelenggaraan dan pengelolaan madrasah, yang 91,4\% swasta, umumnya belum dikelola dengan manajemen yang profesional; (5) Sarana prasarana. Belum memadainya sarana dan prasarana pada sebagian besar madrasah; dan (6) Status. Belum sepenuhnya percaya diri dalam pengelolaan dan penyelenggaraan dan terbatasnya peluang penegrian sehingga madrasah negeri yang umumnya telah memenuhi standar minimal, hanya berjumlah $8,6 \%$.

Adapun problema pendidikan Islam secara eksternal adalah persepsi masyarakat dan pemerintah yang cenderung diskriminatif, sehingga madrasah kurang mendapatkan perhatian, termasuk dalam penyediaan anggaran, bahkan ada yang menganggap sebagai lembaga pendidikan kelas dua setelah sekolah (Muhaimin, 2013: 24).

Pendapat lainnya menjelaskan problema yang dihadapi pendidikan Islam lainnya pada era globalisasi adalah munculnya golongan masyarakat yang sulit percaya, berdasarkan indikator hasil survey the Political and Economic Risk Consultancy tahun 2004 bahwa indeks korupsi di Indonesia mencapai rangking pertama se Asia. Dalam bidang pendidikan, munculnya kegiatan pemalsuan ijazah, tradisi menyontek, plagiasi skripsi, tesis atau disertasi, dan lainnya yang menunjukkan rendahnya sikap amanah masyarakat (Muhaimin, 2006: 84-85). Globalisasi di bidang budaya, etika dan moral, sebagai akibat dari kemajuan teknologi terutama di bidang informasi memberikan berbagai kemudahan untuk mengakses berbagai informasi yang sulit terkontrol, sehingga munculnya sikap sadisme, kekerasan, pemerkosaan, dan sebagainya di kalangan masyarakat (Muhaimin, 2006: 85-86).
Adapun menurut Muzayyin Arifin (2003: 38-41), penyebab krisis pendidikan Islam bersumber dari krisiskrisis orientasi masyarakat pada era global, yaitu: (1) Krisis nilai. Sikap penilaian yang dahulu ditetapkan sebagai yang benar, baik, sopan atau salah, buruk, tak sopan, mengalami perubahan drastis menjadi ditoleransi, bahkan tak diacuhkan orang; (2) Krisis konsep tentang kesepakatan arti hidup yang baik; (3) Adanya kesenjangan kredibilitas; erosi kepercayaan di kalangan masyarakat. Orangtua, guru, penegak hukum mengalami penurunan wibawa dan diremehkan; (4) Beban lembaga pendidikan Islam terlalu besar yang menuntut tanggung jawab moral dan sosiokultural; (5) Kurangnya sikap idealisme dan citra remaja tentang perannya di masa depan bangsa; (6) Kurang sensitif terhadap kelangsungan masa depan; (7) Kurangnya relevansi program pendidikan dengan kebutuhan pembangunan; (8) Adanya tedensi dalam pemanfaatan secara naif kekuatan teknologi canggih; (9) Makin membesarnya kesenjangan di antara kaya dan miskin; (10) Makin bergesernya sikap manusia ke arah pragmatisme yang pada gilirannya membawa ke arah materialisme dan individualisme; dan (11) Makin menyusutnya jumlah ulama tradisonal dan kualitasnya.

Pendapat lainnya menjelaskan bahwa tantangan pendidikan Islam pada era globalisasi yang menjadi problematika pendidikan Islam adalah: (1) Pendidikan cenderung berpijak pada kebutuhan pragmatis, atau kebutuhan pasar lapangan, kerja, sehingga ruh pendidikan Islam sebagai pondasi budaya, moralitas, dan social movement (gerakan sosial) menjadi hilang (Rembangy, 2010: 20-21); (2) Saratnya kurikulum sehingga seolah-olah kurikulum itu kelebihan muatan. Anak- 
anak terlalu banyak dibebani oleh mata pelajaran( Daulay, 2004: 205-208); dan (3) Banyak guru dan tenaga kependidikan masih unqualified, underqualified, dan mismatch, sehingga mereka tidak atau kurang mampu menyajikan dan menyelenggarakan pendidikan yang benar-benar kualitatif (Rembangy, 2010: 28).

Wahid (2008

14-23)

menyebutkan beberapa faktor eksternal yang juga menjadi masalah besar bagi pendidikan Islam dalam menghadapi tantangan globalisasi adalah: (1) Dichotomic. Masalah besar yang dihadapi dunia pendidikan islam adalah dichotomy dalam beberapa aspek yaitu antara Ilmu Agama dengan Ilmu Umum, antara Wahyu dengan Akal setara antara Wahyu dengan Alam; (2) To General Knowledge. Kelemahan dunia pendidikan Islam berikutnya adalah sifat ilmu pengetahuannya yang masih terlalu general/umum dan kurang memperhatikan kepada upaya penyelesaian masalah (problem solving); (3) Lack of Spirit of Inquiry. rendahnya semangat untuk melakukan penelitian/ penyelidikan; (4) Memorisasi. Belajar lebih banyak bersifat studi tekstual daripada pemahaman pelajaran yang bersangkutan. Hal ini menimbulkan dorongan untuk belajar dengan sistem hafalan (memorizing) daripada pemahaman yang sebenarnya; dan (5) Certificate Oriented; pola yang ada pada masa sekarang dalam mencari ilmu menunjukkan kecenderungan adanya pergeseran dari knowledge oriented menuju certificate oriented semata. Mencari ilmu hanya merupakan sebuah proses untuk mendapatkan sertifikat atau ijazah saja, sedangkan semangat dan kualitas keilmuan menempati prioritas berikutnya.

Berdasarkan beberapa pendapat di atas dipahami bahwa globalisasi telah menumbuhkan dua sisi yang paradoks yakni sisi positif dan sisi negative. Dalam sisi positifnya globalisasi memberikan peluang besar bagi semua bangsa dan kalangan untuk berekspresi dan berapresiasi dalam ruang global terhadap berbagai fenomena yang berkembang baik secara politis, ekonomi dan akademik (Askuri, 2003: 259). Sisi negatifnya wajah globalisasi tidak sepenuhnya ramah bagi kemanusiaan seperti kepastian negara-negara dunia untuk bekerja sama sebagai komunitas yang hidup di bumi yang satu dalam mengatasi ketidakadilan global, kemiskinan, kerusakan lingkungan, perdamaian dunia dan lain-lain.

Dari sisi perspektif pendidikan Islam kedua dampak tersebut memberikan implikasi yang siginifikan. Dengan terbukanya cakrawala dunia sebagai imbas perkembangan ilmu pengetahuan dan teknologi, didukung dengan teknologi informasi yang canggih, semakin mempermudah pelaksanaan proses pembelajaran dan pendidikan. Informasi bisa diakses dengan mudah dan murah, transfer dan alih tangan IPTEK pun semakin mudah dan hemat biaya.

Kecendrungan global mendorong umat Islam untuk terus meningkatkan kompetensinya dalam dunia persaingan yang semakin kompetitif. Keterbukaan akses dan kemudahan komunikasi dan transportasi memudahkan para pelajar muslim untuk menimba ilmu di luar negeri. Di satu sisi globalisasi juga memberikan efek yang negatif bagi pendidikan Islam. Pendidikan Islam dihadapkan dengan berbagai problem keummatan yang bersifat universal. Bergesernya paradigma masyarakat dunia yang cenderung materialis dan hedonis, perkembangan ilmu pengetahuan dan teknologi yang begitu pesat tapi tanpa nilai, kegersangan ruhani, dehumanisasi dan lain-lain merupakan problem keummatan yang harus 
dihadapi sebagai imbas negatif dari bergulirnya globalisasi.

Berdasarkan beberapa pendapat tersebut, maka beberapa problematika yang dihadapi pendidikan Islam adalah: (a) Kekurangan sumber daya tenaga pendidik yang profesional dan Kesejahteraan tenaga pendidik masih rendah; (b) Orientasi pembelajaran lebih bersifat kognitif; (c) Manajemen madrasah kurang optimal; (d) Krisis akhlak; and (e) Persepsi masyarakat terhadap madrasah masih banyak kurang baik.

\section{Tenaga Pendidik}

Kekurangan sumber daya tenaga pendidik yang profesional

Pada lembaga pendidikan Islam seperti madrasah problema yang selalu dihadapi adalah kekurangan tenaga pendidik yang profesional. Guru yang mengajar di madrasah sering kali mengampu mata pelajaran yang tidak sesuai dengan latar belakang pendidikannya yang secara teknis disebut mismatch. Banyak ditemui guru mata pelajaran umum di madrasah tersebut merupakan lulusan dari IAIN jurusan PAI. Mereka diberikan tanggung jawab untuk memberikan materi bahasa Indonesia, PKn, bahasa Lampung, IPS, bahkan matematika. Asalkan memiliki pengetahuan sedikit tentang materi itu, maka jadilah dia sebagai guru mata pelajaran tersebut. "Banyak guru dan tenaga kependidikan masih unqualified, underqualified, dan mismatch, sehingga mereka tidak atau kurang mampu menyajikan dan menyelenggarakan pendidikan yang benar-benar kualitatif" (Rembangy, 2010: 28).

Menurut data yang dikeluarkan Dirjen Peningkatan Mutu Pendidik dan Tenaga Kependidikan (PMPTK) Dikti tahun 2007 terdapat 16,22\% guru-guru yang mengalami mismatch alias mengajar tidak sesuai dengan latar belakang pendidikannya. Dari lima bidang studi yang diteliti saat itu terdapat mismatch pada PKN 15,22\%; Pendidikan Agama sebesar 20,80\%; Tata Niaga sebesar 27,88\%; Fisika sebesar 15,53\%; dan Seni sebesar 52,93\%. Dari data tersebut terselip suatu implikasi bahwa mungkin saja sifat korupsi yang tercermin dari wakil rakyat sekarang diakibatkan saat mereka sekolah dulu diajar oleh guru Agama dan PKn yang salah. Guru mismatch ini jelas tidak mempunyai kompetensi untuk mengajar mata pelajaran yang bukan bidang keahliannya sehingga dapat menurunkan mutu aktivitas dan hasil pembelajaran

\section{Kesejahteraan tenaga pendidik masih rendah}

Salah satu alasan di madrasah sering kali kekurangan tenaga pendidik khususnya untuk mata pelajaran umum adalah rendahnya intensif yang diterima mereka. Dengan alasan "ikhlas beramal" sebagai semboyan Kementerian Agama menjadi alasan klasik yang diajukan kepada para tenaga pendidik tersebut. Ironisnya, gaji yang diterima tenaga pendidik (honorer) pada umunya lebih rendah dari gaji para buruh yang telah berdasarkan UMK. Sebagaimana yang ditulis dalam harian Suara Merdeka bahwa Sedikitnya 40 guru bantu dan guru tidak tetap (GTT) dari Kabupaten Demak dan Kota Semarang mengadu ke DPD PGRI Jateng, Jumat (13/2). Mereka mengeluhkan rendahnya gaji bulanan yang diterima dan tidak adanya jaminan kesehatan kerja (Ratnam 2004).

Sedangkan dalam penjelasan UU Nomor 20 Tahun 2003 tentang Sistem Pendidikan Nasional dijelaskan bahwa yang dimasud dengan penghasilan yang pantas dan memadai adalah "penghasilan yang mencerminkan 
martabat guru sebagai pendidik yang profesional di atas kebutuhan hidup minimum (KHM)" (DEPAG RI: 2006, 67). Walaupun memang ada beberapa yayasan penyelenggara pendidikan mengikuti sistim gaji pegawai negeri sipil (Djaelani, 2008).

Salah satu yang penting untuk diperhatikan adalah peningkatan kesejahteraan guru, karena bagaimana ia akan khusus atau tenang mengajar kalau kesejahteraan keluarganya sangat memprihatinkan dan menjadi beban pikirannya. Untuk itu meningkatkan kesejahteraan guru merupakan hal yang sangat penting. Sebagaimana yang disuarakan para guru di Semarang bahwa jaminan kesejahteraan guru akan memberikan ketenangan dalam bekerja yang akan berimbas pada peningkatkan kinerja guru sehingga akan meningkatkan pula mutu peserta didik yang dihasilkan. Selain itu juga akan menambah kuantitas jumlah guru karena adanya jaminan kesejahteraan ini (Sukmadinata, 2005). Para guru pun akan lebih berkonsentrasi dalam menjalankan profesinya, mendidik para peserta didiknya dengan baik dan benar. Mereka tidak perlu kerja serabutan lagi kesana-kemari. Mereka akan memiliki waktu luang yang cukup dan ini tentu saja membantu mereka dalam terus menerus melahirkan ideide kreatif dan inovatif dalam dunia pengajaran. Hasilnya kulitas kerja guru tentu dapat meningkat karena terjaminnya hidup mereka, karena rasa aman secara sosial dan ekonomi.

\section{Orientasi pembelajaran lebih bersifat kognitif}

Kegiatan pembelajaran yang dilaksanakan guru saat ini lebih banyak berorientasi pada pencapaian pada aspek kognitif (pengetahuan). Segala metode dan media serta inovasi yang dilakukan guru dalam upaya agar siswa mampu memahami materi pelajaran dengan baik bukan agar siswa menyakininya, melaksanakannya dan menjadikannya sebagai pedoman dalam berbuat dan bertindak dalam kehidupan sehari-hari. Sebagaimana yang dikemukakan Muhaimin (2013: 56) bahwa pendidikan agama Islam kurang bisa mengubah pengetahuan agama yang kognitif menjadi "makna" dan "nilai" atau kurang mendorong penjiwaan terhadap nilai-nilai keagamaan yang perlu diinternalisasikan dalam diri siswa. Model pembelajaran yang sering dilaksanakan guru hingga saat ini tampaknya lebih cenderung menekankan pada pencapaian perubahan pada aspek kognitif (intelektual), yang dilaksanakan melalui berbagai bentuk model pembelajaran tertentu. Sementara, pembelajaran yang secara khusus mengembangkan kemampuan afektif tampaknya masih sangat kurang mendapat perhatian. Kalaupun dilakukan mungkin hanya dijadikan sebagai efek pengiring atau menjadi hidden curriculum, yang disisipkan dalam kegiatan pembelajaran yang utama yaitu pembelajaran kognitif ataupun pembelajaran psikomotorik.

Banyak ditemukan kegiatan pembelajaran yang dilaksanakan guru terutama dalam pembelajaran agama Islam dengan kegiatan menghafal. Siswa disuruh menghafal berbab-bab materi, agar mampu menjawab soal ketika ulangan dengan baik. Kegiatan pembelajaran dikatakan berhasil apabila siswa mampu menjawab soal ulangan dengan baik. Hal ini mengakibatkan materi ajaran agama hanya sebatas diketahui dan dipahami bukan dihayati dan diamalkan dalam kehidupan sehari-hari.

Sekolah masih menerapkan pola pendidikan yang sama, yaitu 
membangun 90\% kognitif dan hanya $10 \%$ afektif. Sampai saat ini, masih banyak orang yang meyakini keberhasilan anak pada masa depan sangat ditentukan oleh faktor kognitif, sehingga jika IQ mereka rendah mereka akan ditolak di beberapa sekolah dan fungsi kognitif ini diukur dengan satu hal yang bernama IQ (Intelligence Quotient) (Lucy, 2009: 14). Agustian (2001, 17) juga menyatakan bahwa, pendidikan di Indonesia hanya menekankan sisi intelektual/kognitif, padahal sisi EQ dan SQ (afektif) adalah yang terpenting. Oleh karena itu, sudah saatnya pembelajaran bukan hanya berorientasi pada kecerdasan intelektual (IQ) saja, tetapi juga berorientasi pada kecerdasan emosional (EQ) dan juga kecerdasan spiritual (SQ) dalam satu kesatuan yang terintegrasi sehingga akan tercapai keseimbangan antara IQ, EQ, dan SQ.

\section{Manajemen madrasah kurang optimal}

Menurut Muhaimin (2013: 23), penyelenggaraan dan pengelolaan madrasah, yang $91,4 \%$ swasta, umumnya belum dikelola dengan manajemen yang profesional. Banyak ditemukan di madrasah khususnya swasta kurang memiliki kearsipan yang lengkap, pengaturan kurikulum yang tidak jelas, tugas kerja kurang pengorganisasian, kurang pengawasan dan pengontrolan, pelaksanaan pembelajaran yang kurang kondusif.

Sudah menjadi pengetahuan publik, lembaga pendidikan Islam seringkali di kelola tanpa dukungan manajemen yang handal. Kebanyakan lembaga pendidikan malah berada dalam "kerajaan" yayasan keluarga yang dalam penyelenggaraan seringkali mengabaikan prinsip-prinsip dasar manajemen. Alih-alih menerapkan standar proses berbasis ISO, ataupun pendekatan TQM yang berorientasi pada mutu, ataupun mencanangkan manajemen strategis yang mengarahkan pada perencanaan jangka panjang (visioner), membuat rencana jangka pendek pun seringkali diabaikan.

\section{Krisis akhlak}

Dewasa ini berbagai lembaga pendidikan mengalami problema krisis akhlak. Terjadinya pergeseran akhlak dalam diri masyarakat dan peserta didik menjadi masalah yang memerlukan perhatian serius bagi pelaksana pendidikan. Di Amerika kian meningkatnya penyalahgunaan obat, kehamilan remaja, kekerasan antar geng, kriminal, perceraian, dan masalah sosial yang lain. Di sekolah konflik interpersonal meningkat drastis, dan hilangnya kedisiplinan di sekolah (Johnson \& Johnson, 1996: 459-506). Di Indonesia, masalah serupa juga sedang merajalela, seperti banyaknya kriminalitas, korupsi, penyalahgunaan obat terlarang. Di lingkungan lembaga pendidikan terjadi kemerosotan moral peserta didik, ketidakdisiplinan dan kurangnya motivasi belajar.

\section{Persepsi masyarakat terhadap madrasah masih banyak kurang baik}

Selama ini image masyarakat tentang madrasah masih kurang baik. Produk madrasah masih dianggap kurang berkualitas, khususnya dalam ilmu pengetahuan umum. Image masyarakat terhadap Madrasah sering diidentikkan dengan lembaga pendidikan second class, tidak maju, kumuh, dan citra negatif lain masih sering menempel di madrasah, sehingga rendahnya animo masyarakat menengah atas (upper midle class) untuk menyekolahkan anaknya ke madrasah. Hal ini mengharuskan 
madrasah tetap komitmen memperbaiki mutu pendidikan khususnya pendidikan umum tersebut.

A. Malik Fadjar (1998: 76) menyatakan bahwa dalam masyarakat akhir-akhir ini terjadi adanya pergeseran pandangan terhadap pendidikan seiring dengan tuntutan masyarakat (social demand) yang berkembang dalam skala yang lebih makro. Menurutnya, kini, masyarakat melihat pendidikan tidak lagi dipandang hanya sebagai bentuk pemenuhan kebutuhan terhadap perolehan pengetahuan dan ketrampilan dalam konteks waktu sekarang. Lebih dari itu, pendidikan dipandang sebagai bentuk investasi, baik modal maupun manusia (human and capital investmen) untuk membantu meningkatkan ketrampilan dan pengetahuan sekaligus mempunyai kemampuan produktif di masa depan yang diukur dari tingkat penghasilan yang diperolehnya.

\section{Strategi Pendidikan Islam dalam Menghadapi Era Globalisasi}

Ancaman atau tantangantantangan globalisasi tak terelakkan lagi termasuk pada pendidikan Islam. Menurut Abdurahman Assegaf arus globalisasi bukanlah lawan maupun kawan bagi pendidikan Islam, melainkan sebagai dinamisator bagi mesin yang namanya pendidikan Islam. Bila pendidikan Islam mengambil posisi anti global maka akan tidak stationare atau macet dan pendidikan Islampun mengalami intelectual shut down atau penutupan intelektual. Sebaliknya apabila pendidikan Islam terseret arus global dan kehilangan identitas ke Islamannya maka ia akan terlindas.

Oleh karena itu berbagai problematika yang menjadi tantangan pendidikan Islam pada era globalisasi menuntut para pengelola lembaga pendidikan, terutama lembaga pendidikan Islam melakukan nazhar atau perenungan dan penelitian kembali apa yang harus diperbuat dalam mengantisipasi fenomena tersebut, model pendidikan apa yang perlu ditawarkan di masa depan, yang sekiranya mampu mencegah atau mengatasi problema tersebut (Muhaimin, 2006: 86). Pendidikan harus dirancang sedemikian rupa yang memungkinkan para peserta didik mengembangkan potensi yang dimiliki secara alami dan kreatif dalam suasana penuh kebebasan, kebersamaan, dan tanggung jawab. Disamping itu, pendidikan harus menghasilkan lulusan yang dapat memahami masyarakatnya dengan segala faktor yang dapat mendukung mencapai sukses ataupun penghalang yang menyebabkan kegagalan dalam kehidupan bermasyarakat. Salah satu alternatif yang dapat dilakukan adalah mengembangkan pendidikan yang berwawasan global (Zamroni, 2000: 9091).

Menurut Ahmad Tantowi (2009: 90-104), dengan adanya era globalisasi ini perlu adanya rumusan orientasi pendidikan Islam yang sesuai dengan perkembangan zaman dan kebutuhan masyarakat. Orientasi tersebut ialah sebagai berikut: (1) Pendidikan Islam sebagai Proses Penyadaran. Pendidikan Islam harus diorientasikan untuk menciptakan "kesadaran kritis" masyarakat. Sehingga dengan kesadaran kritis ini akan mampu menganalisis hubungan faktor-faktor sosial dan kemudian mencarikan jalan keluarnya; (2) Pendidikan Islam sebagai Proses Humanisasi. upaya mengembangkan manusia sebagai makhluk hidup yang tumbuh dan berkembang dengan segala potensi (fitrah) yang ada padanya. Manusia dapat dibesarkan (potensi jasmaninya) dan diberdayakan (ptoensi 
rohaninya) agar dapat berdiri sendiri dan dapat memenuhi kebutuhan hidupnya; dan (3) Pendidikan Islam sebagai Pembinaan Akhlak al-Karimah. pendidikan Islam harus dikembalikan kepada fitrahnya sebagai pembinaan akhlaq al-karimah, dengan tanpa mengesampingkan dimensi-dimensi penting lainnya yang harus dikembangkan dalam institusi pendidikan, baik formal, informal, maupun nonformal.

Pendapat lainnya menjelaskan strategi yang dapat dilakukan untuk menyiapkan pendidikan Islam yang menghadapi tantangan globalisasi dan mengatasi problema akibat globalisasi adalah: (1) Agama yang disajikan dalam proses pendidikan haruslah agama yang lebih menekankan kepada "kesalehan aktual" bukan semata-mata "kesalehan ritual". Hal ini penting ditekankan mengingat millennium ketiga akan semakin diwarnai selain oleh trust juga oleh kompetisi; (2) Pendidikan Islam harus mempunyai generasi terdidik yang pluralis yang mampu menghadapi kemajemukan baik internal maupun eksternal; (3) Pengembangan sifat pluralis tersebut harus merupakan bagian tak terpisahkan dari upaya besar mewujudkan masyarakat madani yang demokratis, terbuka dan beradab yang menghargai perbedaan pendapat. Justru selalu diupayakan sebgai rahmat bukan sebagai laknat;(4) Masyarakat madani yang diharapkan adalah masyarakat yang penuh percaya diri, memiliki kemandirian dan kreatifitas yang tinggi dalam memcahkan masslah yang diahadapi; dan (5) Pendidikan yang dilakukan harus menyiapkan generasi yang siap berpartisipasi aktif dalam interaksi global, hal iini berarti pengetahuan dan keterampilan yang diberikan harus memiliki relevansi yang kuat dengan trend global tersebut (Baharudin, 2011: 10).
Baharudin (2011: 11) juga memaparkan bahwa pendidikan Islam juga harus memperhatikan beberapa hal lain diantaranya yaitu: (1) Peningkatan mutu sumber daya manusia, diantara tuntutan internal dan tantangan eksternal global, maka keunggulankeunggulan yang mutlak dimiliki oleh peserta didik adalah penguasaan atas sains dan teknologi dan keunggulan kualitas sumber daya manusia(SDM); (2) Menyiapkan kurikulum yang handal yang berwawasan masa kini dan masa depan. Kurikulum ini diharapkan dapat menciptakan manusia-manusia yang memiliki kemampuan yang berkualitas dan memiliki keterampilan dan kecakapan dalam hidup; (3) Sarana dan prasarana yang memadai. Sarana dan prasarana merupakan unsur penting yang sangat menunjang bagi kelancaran dan keberhasilan proses pendidikan. Oleh karena itu, sarana dan prasarana akademik mutlak perlu, baik berupa perpustakaan, gedung, pembelajaran, masjid dan lain sebagainya; (4) Mendekonstruksi metode dan menejemen. Metodologi dan manjemen yang selama ini kita pakai harus dirubah dan dibangun lagi yang baru, yang dapat membawa semangat dan konsep baru sehingga menghasilkan tujuan yang diinginkan sesuai dengan tuntutan modern sekarang ini; dan (5) Pengembangan ilmu sosial profetik. Ilmu sosial profetik adalah ilmu sosial yang dalam pengembangan ilmu selalu didasarkan dengan konsep keilahian.

Abudin Nata (2008: 81-84) menjelaskan strategi yang dapat dilakukan pendidikan Islam dalam menghadapi tantangan globalisasi adalah: (1) Peningkatan mutu akademis; mutu guru/dosen, mutu proses pembelajaran, mutu atmosfer akademis, dan tersedianya sarana prasarana; (2) Peningkatan mutu manajemen pendidikan; dengan menerapkan 
konsep Manajemen Mutu Terpadu; dan (3) Peningkatan keuangan dengan tidak hanya berorientasi dan fokus pada pembiayaan pendidikan dari pemerintah.

Sedangkan menurut Muzayyin Arifin (2003: 46-47), strategi pendidikan Islam dalam menghadapi tantangan modernisasi berkat kemajuan IPTEK sebagai berikut: (1) Motivasi kreativitas anak didik ke arah pengembangan iptek itu sendiri di mana nilai-nilai Islami menjadi sumber acuannya; (2) Mendidik keterampilan memanfaatkan produk iptek bagi kesejahteraan hidup umat manusia pada umumnya dan umat Islam pada khususnya; (3) Menciptakan jalinan yang kuat antara ajaran agama dan iptek, dan hubungan yang akrab dengan para ilmuwan yang memegang otoritas iptek dalam bidang masing-masing; dan (4) Menanamkan sikap dan wawasan yang luas terhadap kehidupan masa depan umat manusia melalui kemampuan menginterpretasikan ajaran agama dari sumber-sumbernya yang murni kontekstual dengan masa depan kehidupan manusia.

Berdasarkan pendapat-pendapat tersebut dipahami bahwa agar pendidikan Islam mampu mengatasi problema dan menghadapi tantangan globalisasi, maka strategi yang perlu dilakukan adalah:

\section{Membangun Paradigma Pendidikan Islam yang sebenarnya}

Melakukan kajian yang mendalam untuk membangun kembali paradigma pendidikan Islam sesuai dengan semangat 'ruhul Islam' yang sebenarnya. Pendidikan Islam yang berpijak kepada Al Qur'an dan AsSunnah. Pendidikan Islam harus berpijak kepada pandangan bahwa Allah SWT menurunkan 'ayat dan 'ilmu Nya melalui dua jalur: jalur formal melalui prosedur Allah - malaikat Rasul; yang disebut sebagai 'ayatul qauliyah (Wahyu, AlQur'an), dan ayatul kauniyah (alam semesta). Ayat qauliyah menjadi petunjuk dan pedoman (minhajul ayah), sedangkan ayatul kauniyah menjadi fasilitas, sarana kehidupan (wasailul hayah). Dengan paradigma demikian, maka dalam pendidikan Islam tidak akan mengalami disintegrasi ataupun dikotomik. Semua obyek bahasan (dalam kurikulum) dipandang sebagai 'ilmu Allah yang harus dipelajari untuk mendapatkan bekalan Petunjuk Hidup (mempelajari 'ayatul qauliyah) dan mendapatkan bekalan untuk memperoleh fasilitas hidup (mempelajari ilmu kauniyah).

Selain itu pendidikan Islam haruslah holistik dan integralistik yaitu harus berorientasi pada pembentukan manusia seutuhnya. Oleh karena itu, materi pendidikan Islam mengandung kesatuan pendidikan jasmani-ruhani, mengasah kecerdasan inetelektual, emosional dan spiritual, kesatuan pendidikan teoritis dan praktis, kesatuan pendidikan individu-sosial, dan kesatuan materi pendidikan keagamaan (diniyah), filsafat, etika dan estetika (akhlak) . Evaluasi pendidikan islam juga dilakukan dalam kerangka kesatuan pengetahuan, sikap dan perilaku.

\section{Melaksanakan Pendidikan Afektif}

Wina Sanjaya (2009: 272) mengungkapkan bahwa pendidikan afektif adalah proses penanaman nilai kepada peserta didik sehingga diharapkan peserta didik dapat berperilaku sesuai dengan normanorma yang berlaku. Muhibbin Syah (1997: 86) menegaskan bahwa pendidikan yang mementingkan kecakapan afektif akan menumbuhkan kesadaran beragama yang mantap. Ia 
akan menolak melakukan perbuatan yang tidak berakhlak bahkan berusaha mencegahnya dengan segenap daya dan upayanya.

Pendidikan atau pembelajaran afektif merupakan suatu kegiatan pembelajaran yang diarahkan untuk membentuk sikap yang berlandaskan nilai-nilai ajaran agama (Islam) melahirkan suatu akhlak mulia dalam kehidupan peserta didiik, bukan hanya pengaruh dari pendidikan yang berlangsung di sekolah, tetapi juga dalam keluarga, dan masyarakat.

\section{Meningkatkan mutu tenaga pendidik}

Guru adalah tulang punggung pendidikan. Oleh karenanya, mutu guru harus mendapatkan kepastian dan jaminan akan kompetensi profesionalnya. Membangun pusatpusat pelatihan dan pengembangan mutu guru sangat membantu menyediakan tenaga-tenaga kependidikan yang handal. Selain itu, dengan adanya pusat-pusat pengembangan mutu guru akan memfasilitasi terjadinya tukar pengalaman dan saling share berbagai ide dan gagasan.

\section{SIMPULAN}

Berdasarkan uraian dalam pembahasan, maka dapat diambil beberapa kesimpulan sebagai berikut: (1) Globalisasi memberikan efek positif dan negatif bagi umat Islam yang kemudian menjadi problema atau tantangan pendidikan Islam untuk mengatasi efek negatif dan menyiakan generasi muslim yang handal menghadapi tantangan globalisasi; (2) Problema yang dihadapi pendidikan Islam menghadapi era globalisasi di antaranya adalah: Kekurangan sumber daya tenaga pendidik yang profesional,
Kesejahteraan tenaga pendidik masih rendah, Orientasi pembelajaran lebih bersifat kognitif, Manejemen madrasah kurang optimal, Krisis akhlak, Persepsi masyarakat terhadap madrasah masih banyak kurang baik; dan (3) Strategi pendidikan Islam dalam menghadapi tantangan globalisasi antara lain: Membangun Paradigma Pendidikan Islam yang sebenarnya, Melaksanakan Pendidikan Afektif, Meningkatkan mutu tenaga pendidik.

\section{DAFTAR PUSTAKA}

Agustian, Ary Ginanjar. 2001. Rahasia Sukses Membangun Kecerdasan Emosi dan Spiritual ESQ Emotional Qoutient Berdasarkan 6 Rukun Iman dan 5 rukun Islam. Jakarta: Penerbit Agra.

Ahmadi. 2001. Islam Sebagai Paradigma Ilmu Pendidikan. Yogyakarta: Aditya Media.

Al-Abrasyi, M. Athiyah. 1970. DasarDasar Pokok Pendidikan Islam. Jakarta: Bulan Bintang.

Ali, Hasmiyati Gani. 2008. Ilmu Pendidikan Islam. Jakarta : Quantum Teaching Ciputat Press Group.

Arief, Armai. 2002. Ilmu dan Metodologi Pendidikan Islam. Jakarta: Ciputat Pers.

Arifin, Muzayyin. 2003. Kapita Selekta Pendidikan Islam. Jakarta: Bumi Aksara.

Arifin, Muzayyin. 1993. Filsafat Pendidikan Islam. Jakarta: Bumi Aksara.

Askuri et. al., 2003. Civic Education. Yogyakarta: Majlid Diktilitbang PP Muhammadiyah.

Baharudin. 2011. Pendidikan Islam dan isu-isu sosial. Yogyakarta: Kurnia Kalam Semesta. 
Lucy, Bunda. 2009. Mendidik Sesuai dengan Minat \& Bakat Anak. Jakarta: PT. Tangga Pustaka.

Daulay, Haidar Putra. 2004. Pendidikan Islam : Dalam Sistem Pendidikan Nasional di Indonesia. Jakarta: Kencana.

Departemen Agama RI. 2007. Al-Quran dan Terjemahannya. Semarang: Toha Putra. 2006. Undang-Undang dan Peraturan Pemerintah RI tentang Pendidikan. Jakarta: Dirjend Pendidikan Islam.

Depdiknas. 2002. Kamus besar Bahasa Indonesia Edisi ke-3. Jakarta: Balai Pustaka.

D. W. Johnson dan R. T. Johnson. 1996. Conflict Resolution and Peer Meditation Programs in Elementary and Secondary Schools: A Review of the Research. Review of Educational. Vol. 66 No. 4: 459-506.

Fadjar, A. Malik. 1998. Madrasah dan Tantangan Modernitas. Bandung : Mizan.

Isma'il SM. 2008. Strategi Pembelajaran Islam Berbasis PAIKEM : Pembelajaran Aktif, Inovatif, Kreatif, Efektif, dan Menyenangkan. Semarang : Rasail.

Maksum, Ali dan Ruhendi, Yunan. 2004. Paradigma Pendidikan Universal di Era Modern dan Postmodern. Yogyakarta: Ircisod.

Marimba, Ahmad D., 1974. Pengantar Filsafat Pendidikan Islam. Bandung: Al-Ma'arif.

Muhaimin. 2013. Rekonstruksi Pendidikan Islam; Dari Paradigma Pengembangan, Manajemen Kelembagaan, Kurikulum hingga Strategi Pembelajaran. Jakarta: Rajawali Pers.

Muhaimin. 2006. Nuansa Baru Pendidikan Islam; Mengurai
Benang Kusut Dunia Pendidikan. Jakarta: RajaGrafindo Persada.

Nata, Abudin. 2005. Pendidikan di Era Global. Jakarta: UIN Jakarta Press. 2008. Manajemen Pendidikan: Mengatasi Kelemahan Pendidikan Islam di Indonesia. Jakarta: Kencana.

Ramayulis. 1994. Ilmu Pendidikan Islam. Jakarta: Kalam Mulia.

Rembangy, Musthofa. 2010. Pendidikan Transformatif : Pergulatan Kritis Merumuskan Pendidikan di Tengah Pusaran Arus Globalisasi. Yogyakarta: Teras.

Syah, Muhibbin. 1997. Psikologi Pendidikan dengan Pendekatan Baru. Bandung: Remaja Rosdakarya.

Sanjaya, Wina. 2009. Strategi Pembelajaran Berorientasi Standar Proses Pendidikan. Jakarta: Kencana.

Sukmadinata, Suara Merdeka, Kinerja Guru Bisa Terpengaruh, 19 Nopember 2005, http://www.suaramerdeka.com/

Tantowi, Ahmad. 2009. Pendidikan Islam di Era Transformasi Global. Semarang : Pustaka Rizki Putra.

Wahid, Abdul. 2008. Isu-isu Kontemporer Pendidikan Islam. Semarang: Need's Press.

Yustina Djaelani, Profesionalisme (Guru) Menjamin Kesejahteraan, http://www.pontianakpost.com/ 26 Mei 2008

Zamroni. 2000. Paradigma Pendidikan Masa Depan. Yogyakarta : Gigraf Publishing.

Zuhairini, et.al.,1980. Methodik Khusus Pendidikan Islam. Surabaya: Usaha Nasional. 